\title{
Similarities and differences between two Hungarian particles for also: szintén and is
}

\author{
Judit Farkas, Bettina Futó, Aliz Huszics, Judit Kleiber, Mónika Dóla \\ and Gábor Alberti \\ University of Pécs, Hungary
}

\begin{abstract}
The paper provides a comparative analysis of the syntax, semantics and pragmatics of two Hungarian particles with the same logical core meaning also: is and szintén. The analysis yields important theoretical implications since it demonstrates how two particles sharing the same logical-propositional/truth-functional core meaning can expand into two different markers. In discourse, is acts as an intensional/metacognitive pragmatic marker in the sense as proposed by Aijmer et al. (2006), while szintén functions as a coherence-signaling discourse marker. The two particles share certain syntactic-semantic properties: neither of them can be followed by a topic, they both have distributive meaning, and both of them can pertain to the noun phrase that they immediately follow, as well as to ordered n-tuples of noun phrases. However, there are also syntactic and pragmasemantic differences between them. Namely, their ordered n-tuples have different word orders; is can function as a pragmatic marker while szintén cannot; szintén can appear as a separate clause, while is cannot (this is presumably related to the fact that szintén can be stressed, while is is obligatorily unstressed); and finally, szintén can have a peculiar discoursepreserving function. We explain the syntactic differences between the two particles using the partial spell-out technique of minimalist generative syntacticians (first applied to Hungarian by Surányi 2009), and the Cinquehierarchy-based approach to Hungarian sentence- and predicate-adverbials (Surányi 2008). We account for the pragmasemantic properties of the pragmatic-marker variant of is in the formal representational dynamic theory of interpretation called ReALIS, already presented in the LingBaW series (Alberti et al. 2016, Kleiber and Alberti 2017, Viszket et al. 2019).
\end{abstract}

Keywords: particles, distributive meaning, Hungarian, pragmatic and discourse markers

\section{Introduction}

The paper analyzes the similarities and differences between two Hungarian particles with the same lexical core meaning ALSO: is [Ish] and szintén [sinteIn].

Is as a particle has had a long history in Hungarian generative literature, with such seminal papers clarifying its basic properties as Brody (1990) and É. Kiss (1992, 2002). There is a lack, 
however, of (widely known and accepted) research on szintén. ${ }^{1}$ Since both particles share the meaning ALSO, it seems only reasonable to start the investigation of szintén in the light of is. Furthermore, their parallel comparative investigation can provide a useful contribution to the universal research into polysemic systems around multifunctional phonetic forms (Fischer 2006: 13-14), with special regards to the subtle distinction between discourse markers and pragmatic markers as proposed by Aijmer et al. (2006). In this terminology, a pragmatic marker is a word or expression that does not contribute to the propositional, truth-functional content of an utterance, while a discourse marker signals coherence relations. In this respect, the major theoretical implication of the parallel analysis of the two Hungarian particles is that it demonstrates a case where two particles sharing the same logical-propositional/truthfunctional core meaning (ALSO) expand into two different markers: is into an intensional/metacognitive pragmatic marker, and szintén into a coherence-signaling discourse marker.

Section 2 provides an overview of the (primarily truth-functional) similarities between the two particles in question. Section 3 presents the (dominantly syntactic) differences between them. Section 4 offers their syntactic representations, including those that capture the coherence-signaling discourse-marker character of szintén. Section 5 is devoted to the demonstration of the pragmatic-marker function of $i s$, through presenting a few types of its pragmatic use. The paper concludes with a summary of the main findings (Section 6).

\section{Similarities between is and szintén}

This section provides an overview of the properties of is that also hold true for szintén, to varying degrees.

\subsection{The distributive nature of is and szintén}

Is is a quantifier: it can neither be followed by a topic (1b), nor can it follow a narrow focus (1c), at least not within the preverbal sentence zone. ${ }^{2,3}$

1 Two separate papers have been published in Hungarian on is and szintén: Huszics (2020) and Futó (2020). The present paper integrates the results of these two studies as a basis, and it has the distinguished aim to disseminate their findings in broader international circles.

2 The grammaticality judgments (on a six-degree scale) referred to throughout the paper are based on the sufficiently uniform - mother-tongue intuition of the six authors. Nevertheless, there might be speakerdependent and/or dialectal differences; these require future research using statistical methods. The following abbreviations are used in the glosses:

(i) case suffixes: ACC(USATIVE), DAT(IVE), INS(TRUMENTALIS), SUP(ERESSIVE);

(ii) agreement suffixes: $1 \mathrm{SG}$... 3PL; 2OBJ (the object is in the second person);

(iii) other suffixes on nouns: PL(URAL), ADJ(ECTIVALIZER);

(iv) affixes on verbs: PREV (preverb), COND(ITIONAL), INF(INITIVALIZER).

3 Hungarian is a discourse-configurational language with a [Top ... Top Q ... Q Foc] preverbal operator zone on the left periphery of sentences. The order of these topics, quantifiers and (narrow) foci in this zone corresponds to their scope hierarchy. In Hungarian, a verb is often accompanied by a preverb, immediately preceding the 
(1) a. Péter is felemelte a zongorát.

Péter also preV.lifted.3sG the piano.ACC

'Péter also lifted the piano.'

b. ${ }^{\star}$ Péter is a zongorát felemelte.

Péter also the piano.ACC preV.lifted.3sG

c. ${ }^{\star}$ Csak a zongorát Péter is fel-emelte /[emelte fel].

only the piano.ACC Péter also preV-lifted.3sG / lifted.3sG preV

Is is known to inherently have distributive meaning (É. Kiss 2002: 110). That is, (1a) means that there has to be at least one other person, apart from Péter, who lifted the piano, and also, that the sentence cannot be assigned the interpretation that 'Péter belongs to a group the members of which lifted the piano together'. ${ }^{4}$

As shown in (2), szintén is also associated with distributive meaning; that is, (2a) also means that there has to be another person besides Péter to have lifted the piano. It also holds true that, similarly to is, in the preverbal sentence zone a szintén-expression can neither be followed by a topic (2b) nor can it follow a narrow focus (2c).

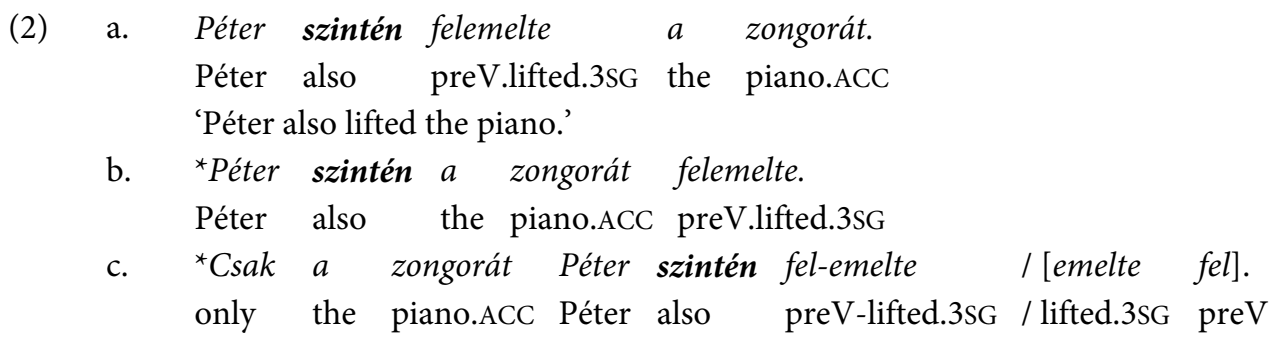

\subsection{More than one is and/or szintén within one clause}

The second syntactic property that the two particles share is that there cannot be two (or more) is- or szintén-occurrences in the preverbal zone (3a-a'); this was pointed out by Brody (1990) in connection with is.

(3) a. *Péter is a zongorát is felemelte.

Péter also the piano.ACC also preV.lifted.3sG

Intended meaning: 'Péter also lifted the piano, too.'

a'. *Péter szintén a zongorát szintén felemelte.

Péter also the piano.ACC also preV.lifted.3sG

verb stem by default. Narrow focus, however, triggers a special order where the verb stem precedes the preverb. For a detailed analysis on Hungarian word order, see É. Kiss (2002).

4 Is might also have a collective reading but only in extremely peripheral/forced contexts such as the following progressive construction:

(i) Péter is emelte (?)(?felfelé l??fel) a zongorát.

Péter also lifted.3sG (upwards / preV up) the piano.ACC

'Péter was also taking part in lifting the piano.'

However, due to the incomplete event-structures of these constructions, it is problematic to interpret the collective/distributive difference. Potential collective readings of is do not form the topic of this paper. 


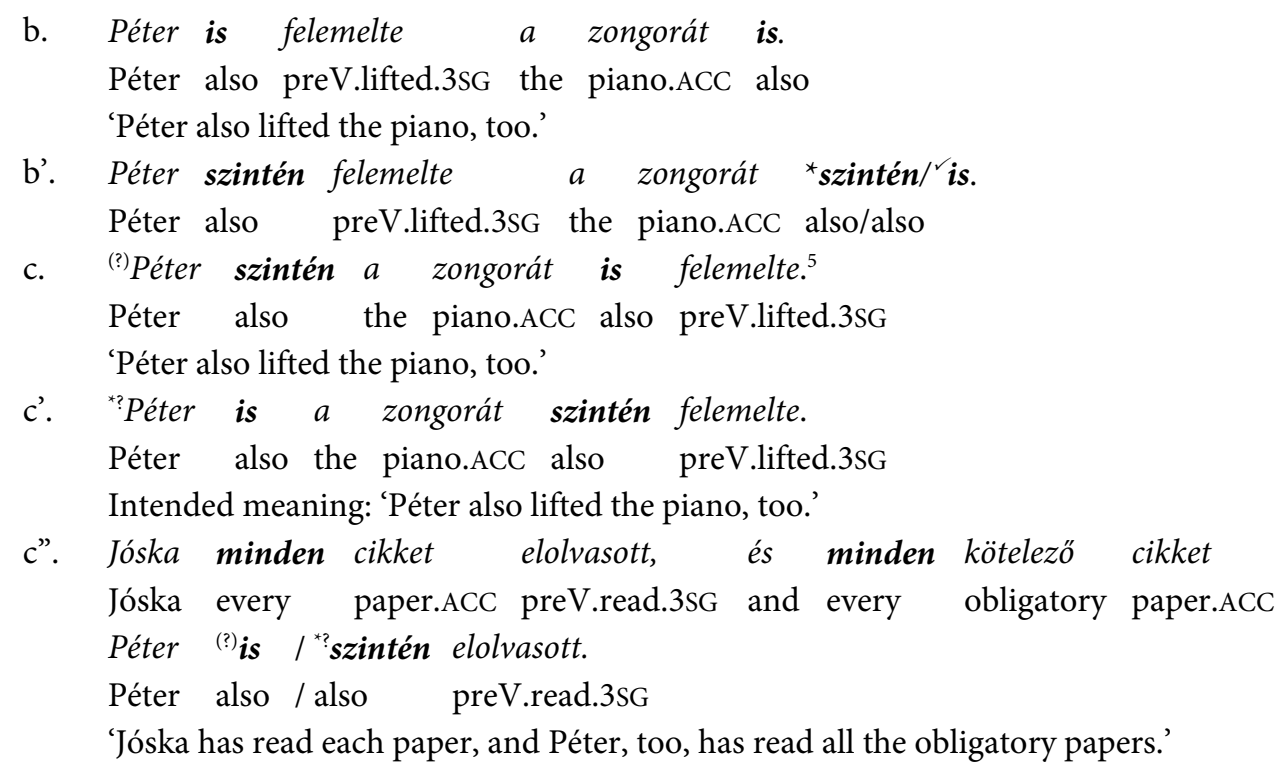

However, in contrast to fully acceptable sentences that contain a preverbal and a postverbal isphrase (3b), those clauses that contain two szintén-expressions are unacceptable (3b'). The sentence only becomes acceptable if the second szintén is replaced with an is (3b',c). However, this does not work the other way round (3c'). A radical difference between the syntax of szintén and is is illustrated in (3c"): in contrast to is, szintén is unacceptable after a quantified expression in the pre- $\mathrm{V}$ zone.

\subsection{The "affiliation" of is and szintén}

Finally, the two particles also share the property that they can both pertain to the noun phrase that they immediately follow (4) - which they primarily do.

(4) Péter Julit Marinak is / szintén bemutatta.

Péter Juli.ACC Mari.DAT also / also preV.introduced.3sG

'Péter introduced Juli to Mari, too. [Péter introduced Juli to some people (e.g. to Ili, Kriszti and Olga), and he also introduced her to Mari.]'

\section{Differences between is and szintén}

In what follows, we discuss several differences between is and szintén, which will lead us to extend our scope of interest to a wide range of further areas.

\footnotetext{
5 This judgment concerns the (undoubtedly less obvious) reading where the constituent [zongorát is] bears a special kind of stress (and interpretation) - characteristic of quantifiers in the comment/predicate zone, as described by Szeteli and Alberti (2018). That is, the same word order is unacceptable if the constituent in question is stressed as a topic-like is-expression. This difference suggests that the position of szintén is exactly after the topic zone and before the comment/predicate zone, in the sense as Szeteli and Alberti (2018) use the terms.
} 


\subsection{Ordered n-tuples in the scope of 'also'}

Both is and szintén can pertain to ordered n-tuples of (nominal) constituents, but in different ways, that is, by different word order options. Szintén can pertain to noun phrases in a number of ways. It can pertain to the noun phrase immediately preceding it (see meaning 1 in (5)), it can pertain to two noun phrases immediately preceding it (see meaning 2 in (5)), and it can even pertain to several noun phrases in the same way (see meaning 3 in (5), for instance).

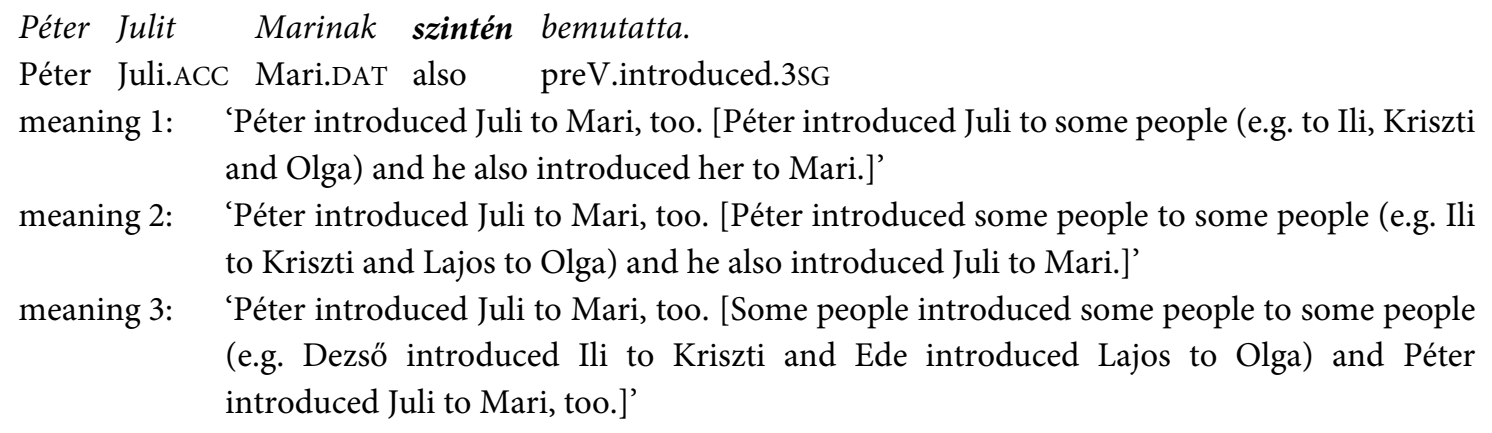
(e.g. Dezső introduced Ili to Kriszti and Ede introduced Lajos to Olga) and Péter introduced Juli to Mari, too.]'

As for $i s$, it has to appear immediately after the first element of the ordered tuple, while the other elements of the tuple are preceded by the verb, see (6a-b). (6c) presents the two sentence schemes. (6d) gives a straightforward semantic restriction on the build-up of the tuples in the scope of is: only referential - or more generally, independently interpretable - expressions can function in these tuples. Proper idiom parts (with no independent reference and/or interpretation) cannot appear in these tuples (that is why (6d) has only one idiomatic reading, in contrast to the two literal readings). This restriction also holds for tuples in the scope of szintén.

$\begin{array}{llll}\text { a. } & \text { Péter is bemutatta } & \text { Julit } & \text { Marinak. } \\ \text { Péter also preV.introduced.3sG Juli.ACC } & \text { Mari.DAT }\end{array}$

meaning 1: 'Péter introduced Juli to Mari, too. [Some people introduced Juli to Mari (e.g. Ili, Kriszti and Olga) and Péter also introduced Juli to Mari.]'

meaning 2: 'Péter introduced Juli to Mari, too. [Some people introduced some people to some people (e.g. Dezső introduced Ili to Kriszti and Ede introduced Lajos to Olga) and Péter introduced Juli to Mari, too.]'

b. Péter Julit is bemutatta Marinak.

Péter Juli.ACC also preV.introduced.3sg Mari.DAT

meaning 1: 'Péter introduced Juli to Mari, too. [Péter introduced some people to Mari (e.g. Betti and Aliz) and Péter also introduced Juli to Mari.]'

meaning 2: 'Péter introduced Juli to Mari, too. [Péter introduced some people to some people (e.g. Ili to Kriszti and Lajos to Olga) and he also introduced Juli to Mari.]'

6 The readings are associated with somewhat different stress patterns. Essentially, the rule is that if a phrase belongs to the tuple in the scope of is in a particular reading, it bears heavier stress than when it does not belong to the scope of is. As a result, there is a (possible but less available) third reading with Péter and Mari in the scope of is (marked by heavier stress). The following situation can be presented as an example for this reading: [Some people introduced Juli to some people (e.g. Ili to Dezső, Kriszti to Olga), and Péter also introduced Juli to Mari.]. 
c. $\mathrm{X}_{1} \mathrm{X}_{2} \quad \ldots \quad \mathrm{X}_{\mathrm{k}}[\begin{array}{llll}\mathrm{Y}_{1} \mathrm{Y}_{2} & \ldots & \mathrm{Y}_{\mathrm{n}}\end{array} \overbrace{[\text { is }+\ldots+\mathrm{V}+\ldots]}$

d. Péter is megütötte a bokáját.

Péter also preV.hurt.3SG the ankle.POss3SG.ACC

literal meaning 1: 'Péter hurt his ankle, too. [Some people (e.g. Dezső and Jóska) hurt their ankles, and Péter also hurt his ankle.]'

literal meaning 2: $\quad$ 'Péter hurt his ankle, too. [Some people hurt themselves at various places (e.g. Dezső hurt his head, and Jóska hurt his arm), and Péter also hurt his ankle.]'

idiomatic meaning: 'Péter is also going to pay for this.'

\subsection{Stress on is and szintén}

Another difference between the two particles is that szintén has stress and it can appear as a separate clause, which two facts are presumably interrelated. This behavior of szintén can be illustrated with a short conversation set in a restaurant, for instance (see (7a)). Is is obligatorily unstressed-it has to cliticize on the constituent that precedes it-and, due to this fact, it cannot appear independently, as shown in (7a).

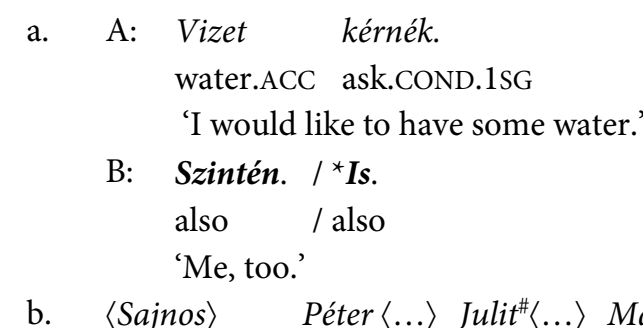

\section{unfortunately Péter Juli.ACC Mari.DAT also preV.introduced.3sG}

The intended meaning is as meaning 2 in (5): 'Péter introduced Juli to Mari, too. [Péter introduced some people to some people (e.g. Ili to Kriszti and Lajos to Olga) and he also introduced Juli to Mari.]' The tuple considered under the intended meaning: [Julit, Marinak]

In contrast to is, szintén does not cliticize on the last noun phrase in the tuple that it pertains to. Moreover, in a sentence like (5), high sentence-adverbials such as sajnos 'unfortunately', szerencsére 'fortunately', szerintem 'according to me', állítólag 'allegedly', valószínüleg 'probably' (Surányi 2008) can readily be inserted between the given noun phrase and szintén (7b). As also presented in (7b), high adverbials can freely appear in several earlier positions on the left periphery of such sentences, with one restriction: they cannot appear inside the sequence of noun phrases in the scope of szintén under the intended meaning (marked by $\left[\begin{array}{lllll}Y_{1} & Y_{2} & \ldots & Y_{n}\end{array}\right]$ in the scheme given in (6c)).

\subsection{Is, and only is, as a pragmatic marker}

Is can be replaced with szintén only if it functions as a distributive quantifier. If is has a pragmatic-marker function in the sense as Aijmer et al. (2006) describe it, their replacement results in ungrammatical constructions, as shown in (8). That is, is can function as a pragmatic marker while szintén cannot. We will return to the topic of the particle functioning as a pragmatic marker later in more detail in Section 5. 
(8) a. Kátyúztak is /*szintén, meg nem is /*szintén.

fixed_road.3PL also / also and not also / also

'They both fixed the roads, and they didn't. [They fixed the road in theory, but they didn't do a very good job at it.]'

b. Kit is /*szintén láttunk tegnap?

who.ACC also / also saw.1PL yesterday

'Again, who did we see yesterday?'

\subsection{Szintén, and only szintén, as a ground-preserving discourse marker}

A further difference between is and szintén is that is always pertains to the element which it follows, while szintén can also pertain to the constituent following it. In the latter case, szintén has a function which can be referred to as a "discourse preserving" function (see Huszics 2020). We try to convey this function in the translations under (9). In this function, szintén can be interpreted as a coherence-signaling discourse marker, as proposed by Aijmer et al. (2006) in their terminology.

(9) a. Tegnap elfogták a bankrablót.

yesterday preV.captured.3PL the bank_robber.ACC

(És) szintén tegnap Tóth bíró elítélte a büntársait.

and also yesterday Tóth judge preV.sentenced.3SG the accomplice.PL.ACC

'The bank robber was caught yesterday. (And) also yesterday, judge Tóth sentenced his accomplices.'

b. Ibi hozta be a gyilkost.

Ibi brought.3SG preV the murderer.ACC

(És) szintén Ibi oldotta meg a bankrablási ügyet.

and also Ibi solved.3sG preV the bank_robbery.ADJ case.ACC

'It was Ibi who brought in the suspect. (And) it was also Ibi who solved the bank robbery case.'

b'. ?[Ibi be-hozta a gyilkost.

Ibi preV-brought.3SG the murderer.ACC

(És) szintén Ibi meg-oldotta a bankrablási ügyet.]

and also Ibi preV-solved.3SG the bank_robbery.ADJ case.ACC

'Ibi brought in the suspect. (And) it can also be said about Ibi that she solved the bank robbery case.'

If the ground-preserving szintén pertains to an argument (9b-b') and not to an adjunct (9a), the argument has to appear in focus position (Huszics 2020). It requires future research to establish the kinds of satellites that can appear both in topic and in focus position, and the kinds of satellites that can appear only in focus position. At this point though, it can be stated that adjuncts can appear in both positions (presumably due to their independent interpretability, which is expectable with topic-like functions), while central arguments (viz. nominative and accusative case-marked ones) can only appear in focus, with non-central arguments seemingly showing an in-between (but uneasily characterizable) behavior.

\section{Syntactic representations}

This section provides syntactic representations for various constructions containing is or szintén. 


\subsection{The syntactic representation of is}

First let us consider the structure belonging to (6b), repeated here as (10) in meaning 2. This meaning can be regarded as a realization of the general scheme presented in (6c), as follows: $\mathrm{X}_{1}=$ Péter, $\mathrm{k}=1, \mathrm{n}=2,\left[\mathrm{Y}_{1}, \mathrm{Y}_{2}\right]=$ [Juli, Mari], see (10b).
(10) a.
$\begin{array}{llll}\text { Péter Julit } & \text { is } & \text { bemutatta } & \text { Marinak. } \\ \text { Péter Juli.ACC } & \text { also } & \text { preV.introduced.3SG } & \text { Mari.DAT }\end{array}$ and Lajos to Olga) and he also introduced Juli to Mari.]'

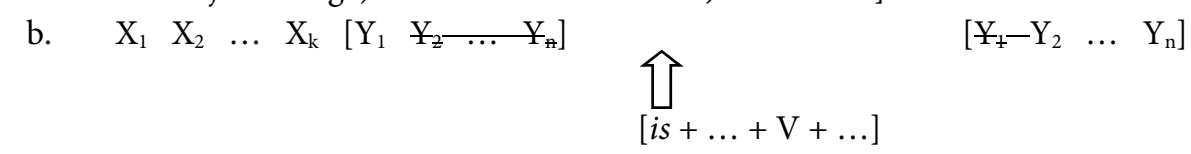

'Péter introduced Juli to Mari, too. [Péter introduced some people to some people (e.g. Ili to Kriszti

The structure is based on Grohmann's (2003) theory of Prolific Domains - in particular, on the version proposed for Hungarian by Farkas and Alberti (2017). The triangle under the vP node signals that the internal build-up of the thematic domain $(\Theta \Delta)$ is irrelevant here. In the $\Phi \Delta$, CentPs host central arguments (i.e. the subject and the object), while NonCentPs host noncentral arguments. The order of CentPs and NonCentPs is free; it is based on Behaghel's Law, often used by É. Kiss (e.g. 2009), which predicts that the optimal order of the satellites of V at the right periphery of the Hungarian sentence is the following: heavy phrases tend to come last. In harmony with this principle, the basically free word order (determined mainly by the Behaghel's Law) appearing in Hungarian in the postverbal zone is expressed as such: the highest phrase in the $\Phi \Delta$ is AspP, whose modifier is occupied by the preverb expressing the aspect of the sentence, and to whose head the verb moves.

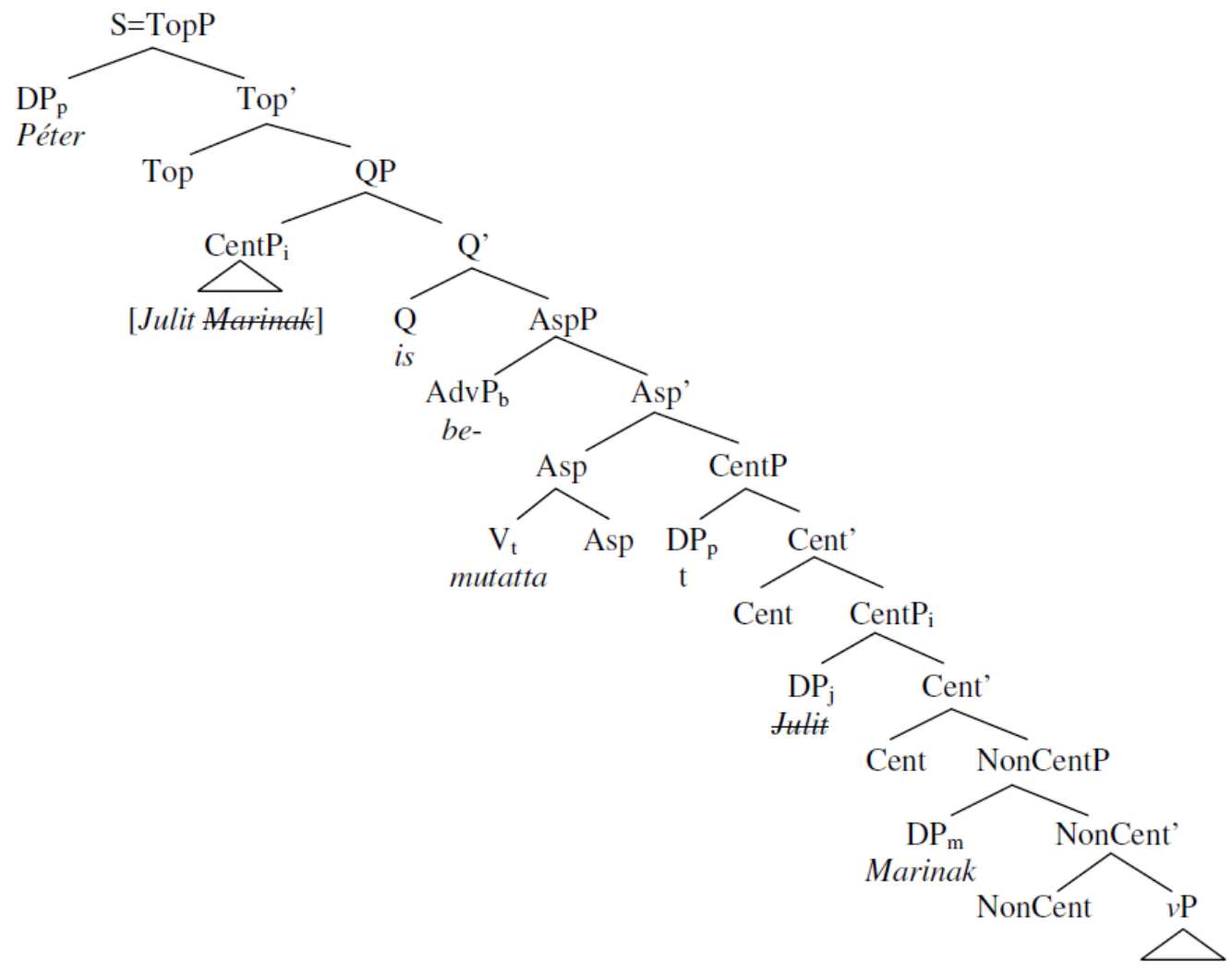

Figure 1: The syntactic representation of (10a) 
As the particle is pertains to a whole proposition in (10), a whole CentP has to appear (in the $\Omega \Delta$ ) in the modifier of the quantifier, the head of which is occupied by the particle itself. Due to the fact that is is obligatorily unstressed and it has to cliticize on the head of the constituent it pertains to, the CentP is only partially spelt out in the modifier in question $\left(\left[\mathrm{Y}_{1}\right.\right.$, $\left.\left.¥_{z}\right]\right)$; the rest of the CentP is spelt out in its base-generated position $\left(\left[Y_{t}, Y_{2}\right]\right)$. ${ }^{7}$ The subject (Péter) appears as a topic, since it does not belong to the ordered n-tuple in question (it plays the role of $\mathrm{X}_{1}$ in (10b) and (6c)).

\subsection{The syntactic representation of szintén}

Figure 2 presents the syntactic structure of the corresponding sentence containing szintén (see (5) in meaning 2), repeated here as (11).

(11) a. Péter Julit Marinak szintén bemutatta.

Péter Juli.ACC Mari.DAT also preV.introduced.3sG

'Péter introduced Juli to Mari, too. [Péter introduced some people to some people (e.g. Ili to Kriszti and Lajos to Olga) and he also introduced Juli to Mari.]'

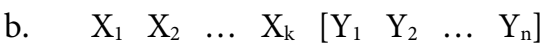

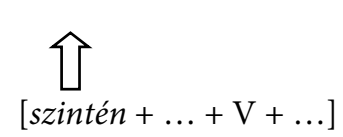

This meaning can also be regarded as a realization of the general scheme presented in (6c), with the same specification: $X_{1}=$ Péter, $k=1, n=2,\left[Y_{1}, Y_{2}\right]=$ [Juli, Mari], see (11b). The crucial difference is that szintén has no "addiction" to insertion but behaves as a Cinquean middle (predicate-) adverbial, as proposed by Surányi (2008) (on the basis of word-order facts and the stressed status of szintén), which projects as an AlsoP left-adjacent to the field of the complex predicate (AspP here). Witnessed by ( $7 \mathrm{~b}$ ) in 2.2, projections of high sentences-adverbials (such as sajnos 'unfortunately') can appear between the lower TopP and this AlsoP (apart from when they appear between the two TopPs and above the higher TopP). That is why the specifier of AlsoP is assumed to only contain the trace of the remnant with the phonetic realization Julit Marinak. This latter sequence is considered to form a unit, in order to account for the fact that no high adverbial can appear between Julit and Marinak (as also illustrated in (7b)). This unit is assumed to occupy the specifier of a topic, instead of that of a quantifier, due to the data shown in (3c') in 1.2: this way, the ill-formed status of the word order in question can be attributed to the rule that a quantifier cannot take scope over a topic. ${ }^{8}$ This implies the following complex semantics for szintén: its use relies on a complex predicate in an earlier clause, and

\footnotetext{
The partial spell-out technique was first applied to Hungarian by Surányi (2009).

8 The same rule accounts for the well-formed status of (3c): the noun phrase before the AlsoP is a Topic, which is permitted to take scope over the is-quantifier after the AlsoP. AlsoP is the leftmost element of the comment / predicate zone of the Hungarian sentence structure, immediately after the topic zone. Quantifiers can appear in both sentence zones (Szeteli and Alberti 2018), resulting in this general structure (H: high adverbials, ${ }^{*}$ : Kleene star, which means that $0,1,2$ or more copies of the given category can occur):

[Topic zone $\mathrm{H}^{\star}$ Top $^{\star} \mathrm{H}^{\star} \mathrm{Top}^{\star} \mathrm{H}^{\star} \mathrm{Q}^{\star} \mathrm{H}^{\star}$ ] [Comment zone Also $\mathrm{Q}^{\star}$ Foc ...]
} 
szintén associates the new copy of this (in the given clause) with a new tuple of referents. ${ }^{9}$ The distributive character can be explained as follows: the new topic does not refer to a participant in the original (or old) eventuality itself, but to a participant in an eventuality which is of the same type as the antecedent eventuality, but another instance of that type.

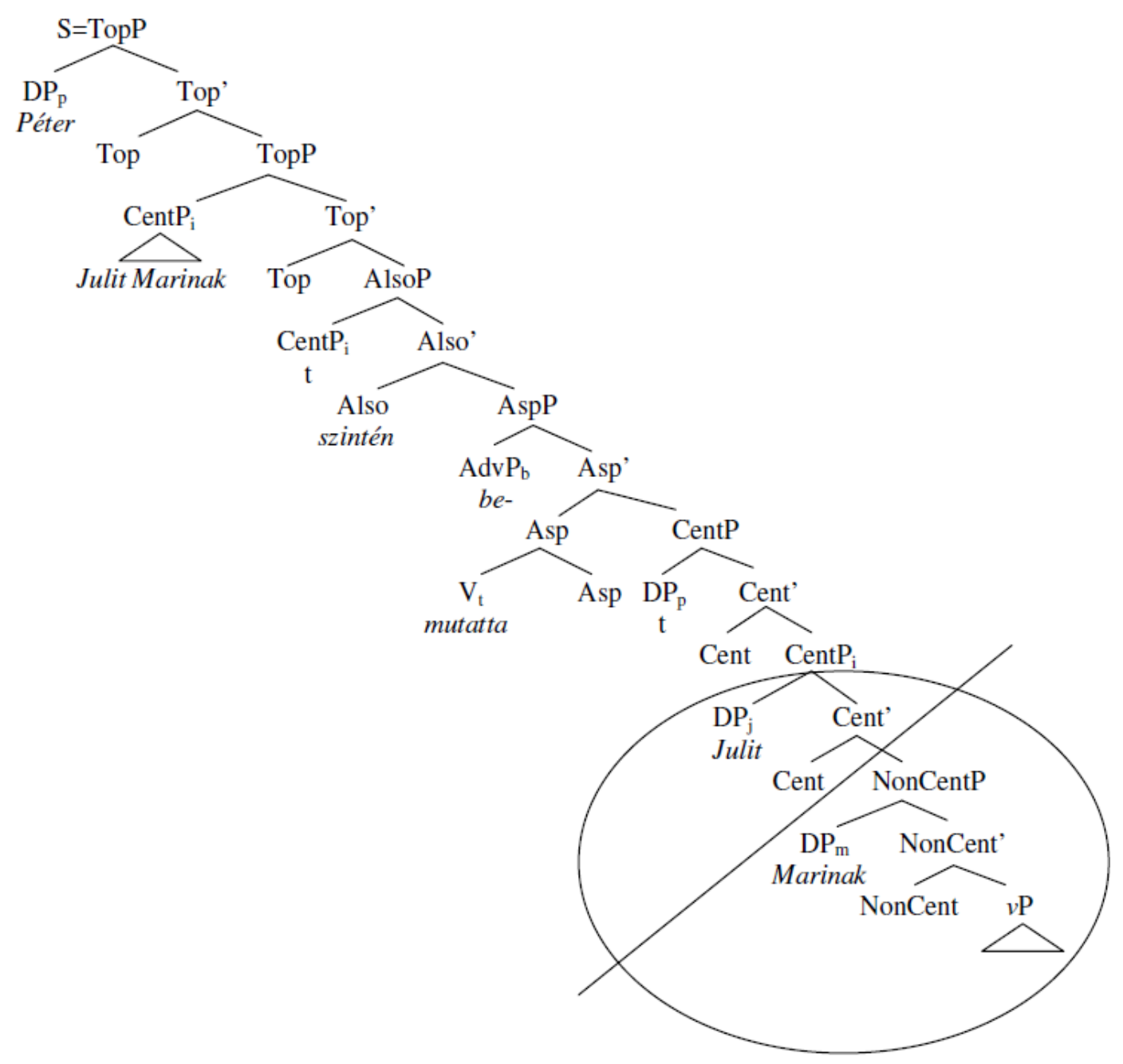

Figure 2: The syntactic representation of (11a)

\subsection{The syntactic representation of the "ground preserving" szintén}

The final structure we consider is the one where szintén has a discourse preserving function; see (9a), for instance, repeated here as (12)). Just like in 3.2, its semantics relies on the association of something old with something new; except here, certain elements in the topic zone of an earlier clause are exploited. This anchoring information is associated with a new complex predicate, whose projection appears in the complement of the given Also head.

(12) (És) szintén tegnap Tóth biró and also yesterday Tóth judge

9 The new copy of the antecedent predicate can be elided. Julit Marinak szintén - this verbless sequence of words, for instance, can serve as a well-formed alternative to (11a) in contexts with appropriate antecedents. 
elitélte a büntársait.

preV.sentenced.3sG the accomplice.POSs3SG.PL.ACC

'[The bank robber was caught yesterday.] (And) also yesterday, judge Tóth sentenced his accomplices.'

As formulated in Huszics (2020), the specifier of the AlsoP contains the antecedent clause, which is then to be regarded as still "active" in the discourse: the antecedent clause 'yesterday, the bank robber was caught' is referred to by the anaphoric element pro-Top'. ${ }^{10}$ Given the fact that this kind of szintén must be cliticized on the constituent in the specifier from the left, the word order changes in the Phonological Form (resulting in the sequence szintén tegnap). Here szintén functions as a high sentence-adverbial (old topic(s) with a new predicate), in contrast to the predicate-adverbial variant of szintén (new topic(s) with an old predicate).

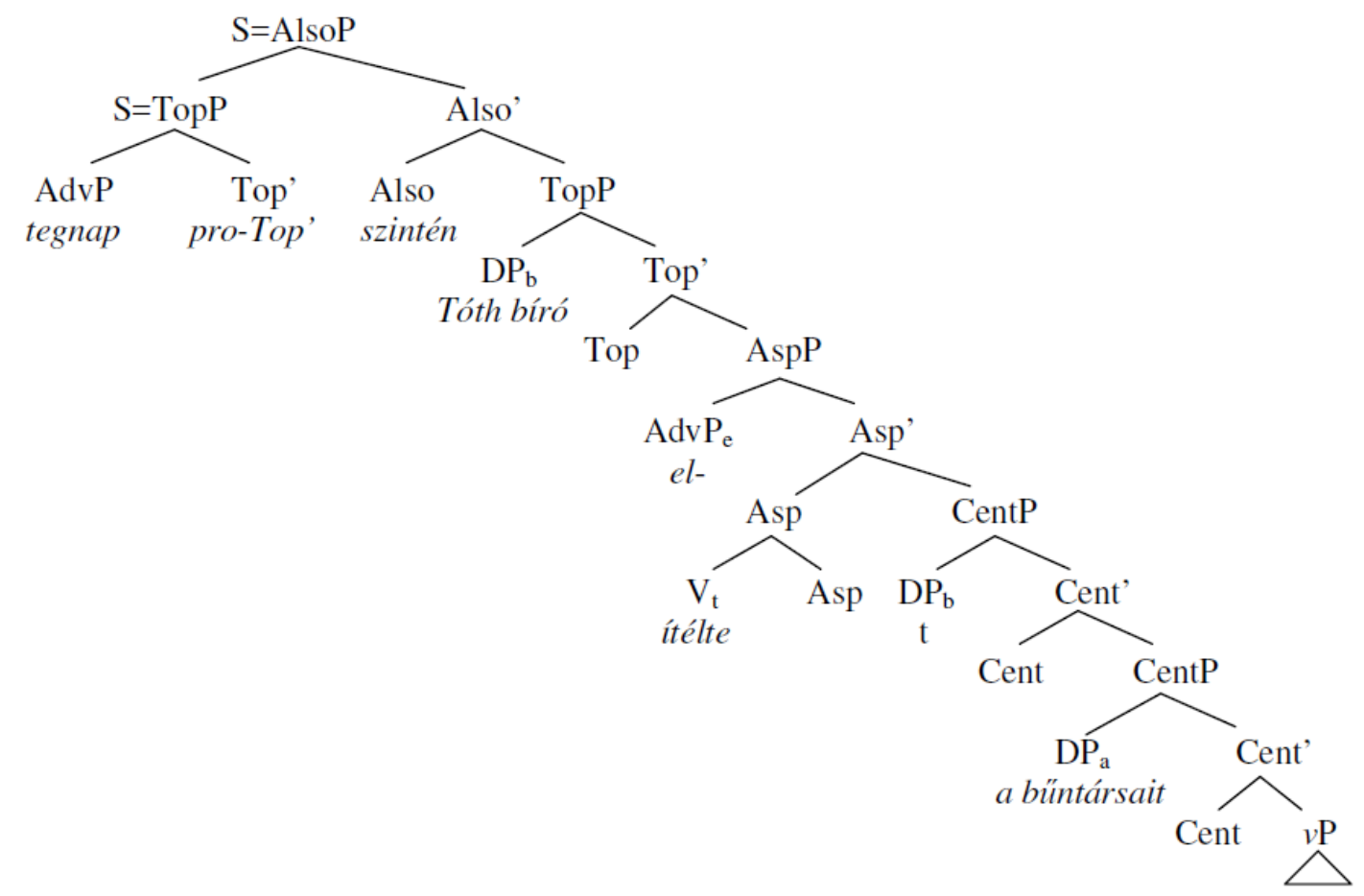

Figure 3: The syntactic representation of (12)

\section{Is as a pragmatic marker}

As mentioned previously (see (8) in Section 3), the particle is does not only have a logical role, but it can also function as a pragmatic marker - as used in the terminology proposed by Aijmer et al. (2006). In this role, it cannot be replaced with szintén (NB: the function of is can be called 'logical' if the given function can be expressed by a corresponding szintén-expression). In this section, we present how the different kinds of is can be systematically differentiated from one another, and how they can be accurately characterized in a formal representational dynamic

10 Bánréti (1992: 789) accounts for various elliptical constructions by using empty proposition-level pronominal expressions. In his example (136'), a pro-V' refers to a situation with a boy looking at a girl. The sentence in question consists of a single word: Hosszasan 'at length'. In the same way, Tegnap 'yesterday' can serve as a short answer to the question: When was the robber caught? 
theory of interpretation called ReALIS (Reciprocal and Lifelong Interpretation System). ${ }^{11}$ These observations are the first steps towards revealing the complex polysemic network of the particle is in full (Fischer 2006: 13-14), with special regard to the subtle differentiation between pragmatic markers and discourse markers, such as szintén. As mentioned in the Introduction, a pragmatic marker in the terminology of Aijmer et al. (2006) is a word or expression that does not contribute to the propositional, truth-functional content of an utterance, while a discourse marker signals coherence relations.

\subsection{The pragmasemantic characterization of the emotive is}

The example below (13a) serves to illustrate one of those cases where the role of is can be "nonlogical". Here, hárman is (three+also) does not refer to a set of more than three (that is, at least four) students. Instead, is yields an exclamative sentence, with the intensional characteristics given in (13b).

(13) a. Hárman is megoldották ezt a feladatot!
three also preV.solved.3PL this.ACC the task.ACC
'There were (as many as) three people who solved this task (separately).' =e
$\begin{array}{ll}\mathrm{iB} \downarrow \in{ }^{\prime}-3 & \text { [At an earlier point of time, I considered it quite unlikely that e should take place.] } \\ \text { [e taking place has a considerable emotional impact on me, either a positive or a negative one] }\end{array}$

The pieces of intensional information involved in this situation are presented with the formalism of $\Re$ eALIS. Essentially, the strings (e.g. iBuB $\downarrow$ ) represent possible worlds of their holder, which is indicated by the first symbol in them ( $\mathrm{i}=\mathrm{I}$ (the speaker), $\mathrm{u}=$ you (the listener), $\mathrm{o} / \mathrm{o} / \mathrm{o} / \ldots=$ ' underspecified holders'). The second symbol represents the modality of the possible world that the holder of the world (indicated by the first symbol) associates with the propositional content of the sentence. It can be, among others, a belief (B), a desire (D) or an intension (I). The modality is followed by an element of the set $\mathrm{T}=\{\downarrow, \uparrow, \bullet\}$, which indicates the temporal properties of the world ( $\downarrow$ ' for past, ' $\uparrow$ ' for future, ' $\bullet$ ' for present, in the string usually unmarked). If such a string is followed by a new holder, a new modality and a new temporal property, it means that it is embedded into the previous wordlet. This technique of reciprocity

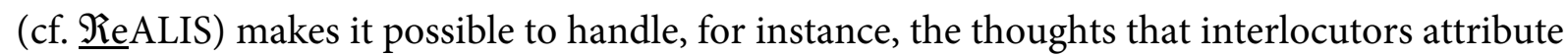
to each other in the course of mind reading. A scale is also introduced for the values referring to false $(-5)$, true $(+5)$, and underspecified (0) information, and to various degrees between them (which more or less correspond to Farkas and Roelofsen's (2017) credence levels). As for the apostrophes, relative to the value -3 , the complex symbol ' -3 ' denotes the interval $\{-5,-4$,

11 ReALIS is presented, among others, in Alberti (2011), Alberti and Kleiber (2015), Alberti et al. (2019a), in addition to Alberti et al. (2016), Kleiber and Alberti (2017), Szeteli et al. (2019) and Viszket et al. (2019), published in Poland. We have opted for this theory due to its integrative character. On the one hand, ReALIS is a representationalist counterpart of Lauer's (2013) and Farkas and Roelofsen's (2017) antirepresentationalist dynamic pragmatics in the post-Montagovian world of formal semantics. On the other hand, it simultaneously aims at serving as a "cognitively viable linguistic representation," as formulated in Andor's (2011:1) interview with Searle. 
$-3,-2,-1\}$ around the precise value -3 . The relation iBuB $\downarrow \in{ }^{`}+4 \cdot-5$ thus means that "I am more or less convinced that you thought that a given information unit $e$ is false."

Thus, (13b) provides possible-world indices. The first index defines the possible world of certain earlier assumptions of the addresser (modified later). ${ }^{12}$ The second one "collects" states of affairs immensely desirable or, on the contrary, definitely undesirable for the addresser. We claim that this underspecified situation should be regarded as a linguistically and conventionally encoded part of the meaning of the given type of is (cf. Farkas and Roelofsen 2017: 237). In a particular conversation, the polarity value can typically be decided on the basis of world knowledge. Success in solving tasks is typically desirable, but the particular context may imply the opposite polarity value.

\subsection{The pragmasemantic characterization of is meaning 'and so it happened'}

The second type of is we discuss is the one that can be referred to as the Ugy is lett 'And so it happened' type. This type is mentioned in Alberti and Farkas (2018: 41), where its syntactic properties are accounted for. Here (see (14)), we present the crucial elements of the pragmasemantic contribution of the type to the discourse, based on the three examples in (14a-a").

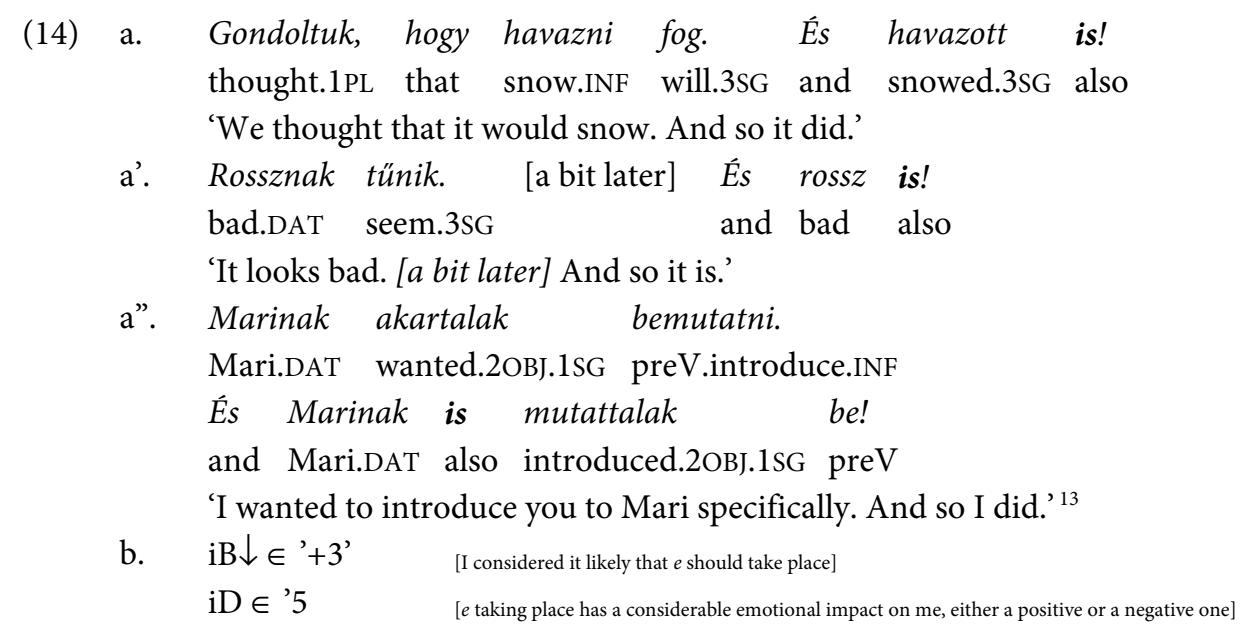

\subsection{The pragmasemantic characterization of the is of refutation}

Compared to the intensional profile in (13b), the one in (14b) also contains a substantial emotional impact, but here, the anticipatory epistemic state is positive. In example (14a"), this is not expressed explicitly in the sentence before the one including the is, but it is obvious that committed volition tends to yield success.

${ }^{12}$ In $\Re$ eALIS, the term addresser is used with the aim of distinguishing (and then truth-conditionally comparing) the 'addresser role' as a conventionalized intensional profile (to be calculated based on sentence types and discourse markers) from 'speaker' - as a conscious psychological ego with permanently changing information states.

13 The first syllable of (14a") in both occurrences of the noun Marinak is pronounced with the (same) peculiar narrow-focus stress. 
The third type we discuss is a kind of denial, as presented in (15b), an answer to (15a). This construction is typically used to explicitly refute some presupposition within the content of the antecedent statement. Hence, a detailed formal analysis of this type requires the "lifelong" character of ReALIS (cf. ReALIS). This means that the basis of interpretation contains the interlocutors' momentary information states as lifelong-built (Alberti 2000) discourse representation structures (Kamp et al. 2011). These structures can obviously contain both the contextual information in the interlocutors' episodic memories and the scripts in their semantic memories (Leiss 2014), required to calculate the connection between the (b-b')-sentences and the (a)-sentence. The (15a+b') dialogue, for instance, can be explained with reference to a script which is available to the interlocutors and which contains information on the relation between dancing and potential dance lessons.

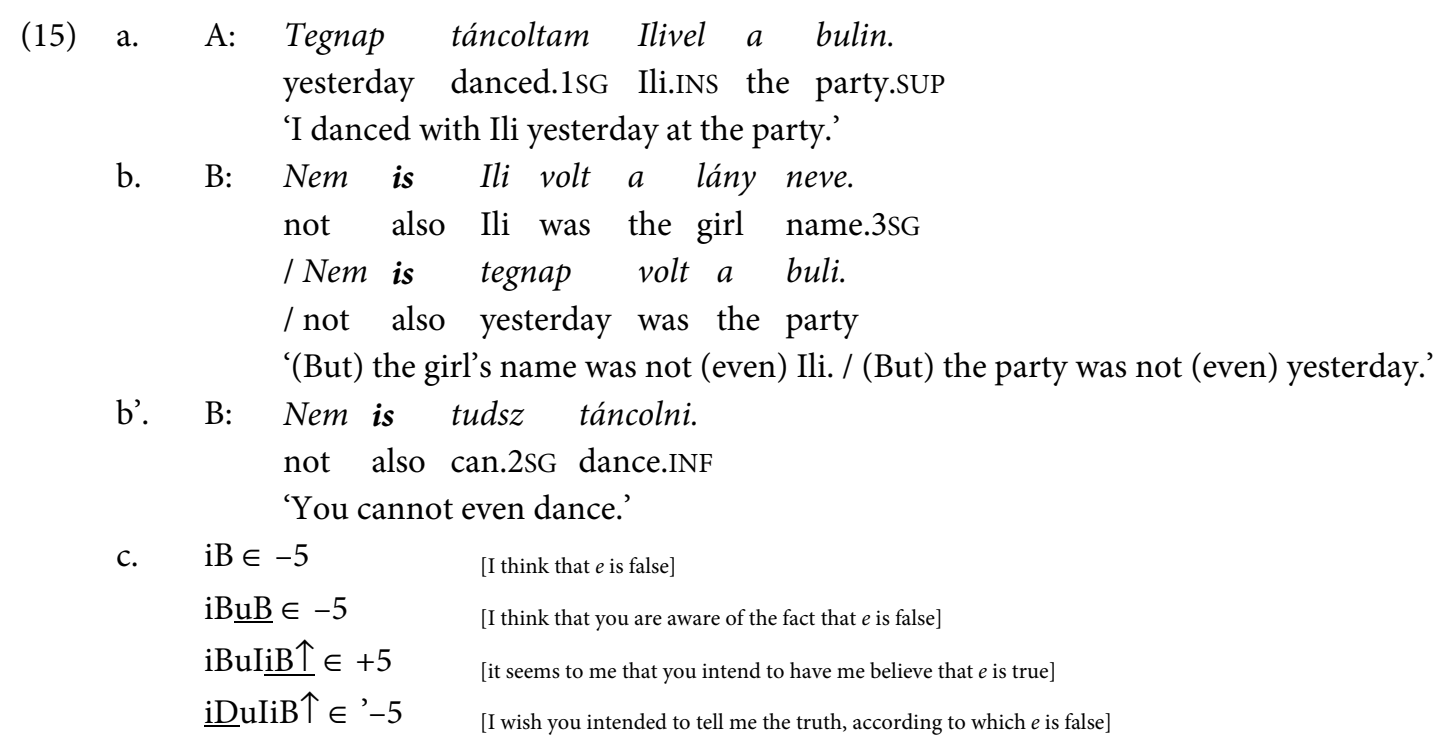

(15c) presents the possible-world indices that we propose as the definitive factors of the conventionalized intensional profile of the "refutative" is-construction. The information in question (denoted by $e$ above) is the content of the sentence in (15a). Essentially, the profile expresses the addressee's stance according to which the addresser should stop pretending as if (15a) were true.

\subsection{The pragmasemantic characterization of the is of "contradictions"}

The fourth type of is we discuss displays the form [p and not $\mathrm{p}$ ] of a logical contradiction, which is regarded as a non-contingent but constantly false expression in logics (16a-a'). The given double-is-construction, however, does provide some contingent intensional contribution. It becomes possible like this: the two clauses that the construction consists of concern two different possible worlds; and it is not impossible at all but definitely typical that alternative possible worlds support a proposition and also its opposite. 


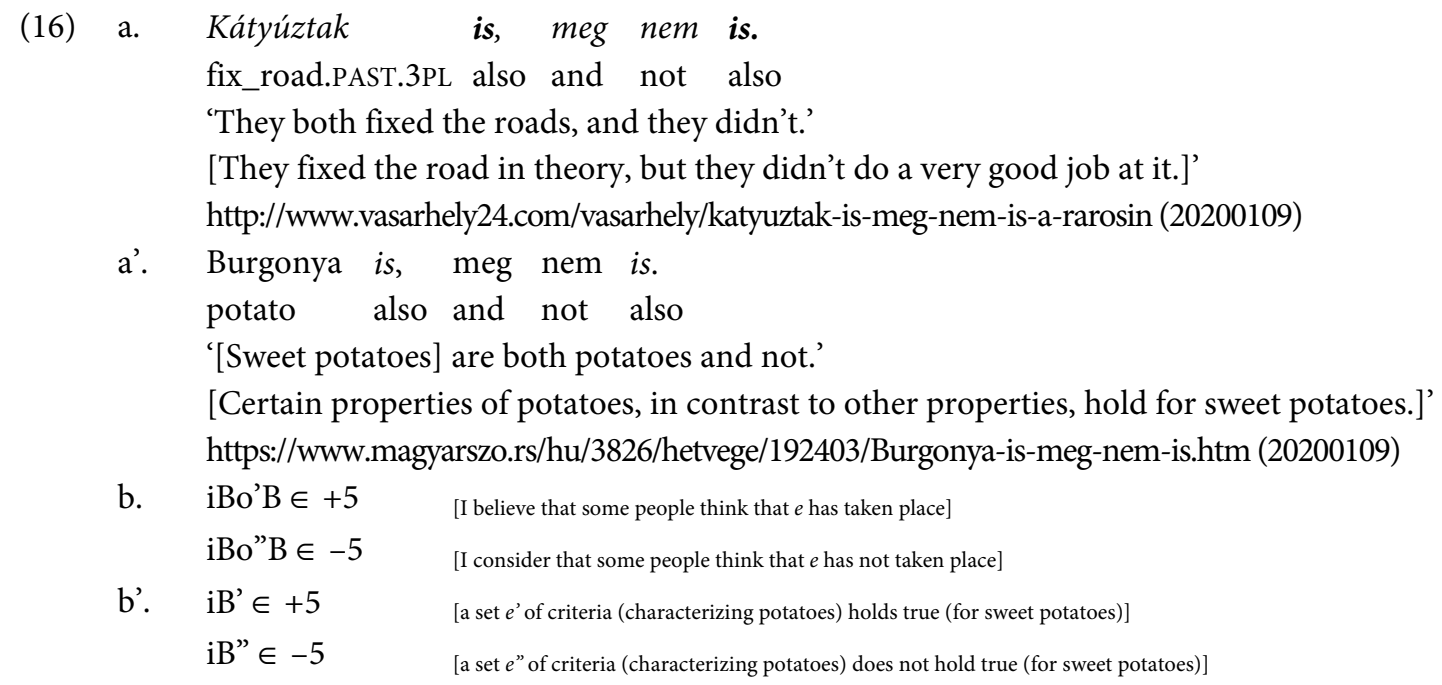

Based on the analyses of a wide range of relevant Internet data, we hypothesize that the intensional profile of the construction under investigation is highly underspecified. The common factor in the data is that the interpretation of the same content in the same possible world is somehow avoided. Apart from this, the interpretation of the utterance is often extremely vague. Regarding the sentence in (16a), the profile proposed in (16b) accounts for the apparent contradiction in that it assumes that the addresser articulates the opinions of different groups (o' and o") of people. As for the profile (16b'), proposed for the sentence in (16a'), our analysis relies on the script- and schema-based technique of interpretation in ReALIS, as exemplified in (15b'). For something to qualify as a potato requires the satisfaction of a set of criteria more or less known to the interlocutors. Thus, the two clauses in (16a') should be regarded as ones that concern two different sets of properties related to sweet potatoes (viz. the potato-like and the non-potato-like properties, respectively).

\subsection{The pragmasemantic characterization of the basic metacognitive is}

The last type of is we discuss here to demonstrate the non-logical uses of is-where it cannot be replaced with szintén-is the one that can be referred to as the metacognitive is; the nearest English equivalent for this is could be 'again' (17a).

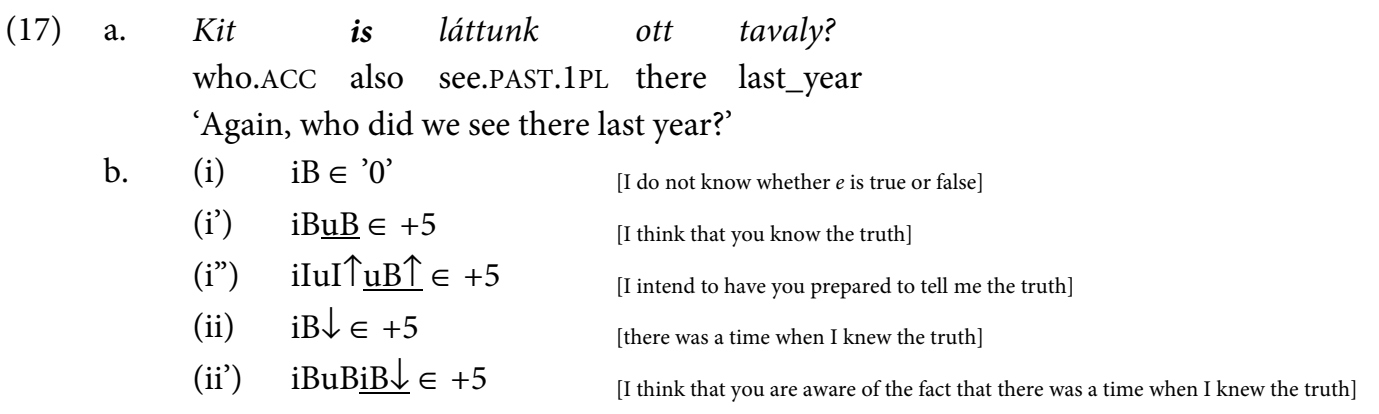

The intensional profile of the metacognitive is (at least, of this particular subtype, see Futo (2020)) is presented in (17b.ii-ii'). The addresser is scanning his/her own lifelong mind representation and realizes that there is some information that he/she had had earlier (17b.ii) 
but is now missing from his/her current information state (17b.i). They also realize that, luckily, this is a piece of information that they are likely to (have) share(d) with the addressee (17b.ii'). Note that the profile elements given in (17b.i-i") are necessary for elucidating the functioning of the wh-word+is construction (the addresser asks for the missing information), but they belong to the general interrogative intensional profile, discussed in Alberti et al. (2019b) and Viszket et al. (2019), among others.

\section{Summary}

The purpose of the paper was to discuss two Hungarian particles with the same logical core meaning ALSO: is and szintén. Since is has been extensively studied in Hungarian generative literature (e.g. Brody 1990 and É. Kiss 1992, 2002) while szintén has scarcely been paid attention, we described the two particles in relation to each other, using the already available descriptors for is as a point of departure for the description of szintén. The parallel analysis of the two particles yielded novel observations for the syntax and pragmasemantics of both particles, as summarized below (see Section 2 for details):

I. Both szintén and is have a distributive meaning.

II. Neither is, nor szintén can be followed by a topic, and neither of them can follow a (narrow) focus.

III. Is and szintén can be combined within one clause, with certain restrictions on word order.

IV. Both szintén and is can pertain to ordered n-tuples of noun phrases (as a generalization of the case $\mathrm{n}=1$ ), but in syntactically different ways.

V. Is is obligatorily unstressed, while szintén bears stress, with the exception of its ground-preserving use, when it can be regarded to function as a discourse marker (Aijmer et al. 2006).

VI. Szintén can appear as a separate clause, while is cannot.

VII. Is can function as a pragmatic marker (Aijmer et al. 2006) while szintén cannot.

After an overview of the similarities and differences (Sections 2 and 3), we demonstrated how the syntactic characteristics of the two particles can be captured by the partial spell-out technique used in some branches of minimalism (Surányi 2009), and we classified szintén as a high sentence-adverbial (Surányi 2008) - in contrast to the clitic-like is (Section 4). In what followed, we drew up a pragmasemantic system for those usages of is where the particle cannot be replaced with szintén - i.e. the cases where is functions as an intensional/metacognitive pragmatic marker, as opposed to szintén, which acts as a coherence-signaling discourse marker (Section 5). For this analysis, we used the framework of the formal representational dynamic theory of interpretation called ReALIS (see, for instance, Alberti et al. 2016, 2019; Szeteli et al. 2019, and Viszket et al. 2019). 


\section{References}

Aijmer, K., A. Foolen, and A.-M. Simon-Vandenbergen. 2006. Pragmatic markers in translation: A methodological proposal. Approaches to Discourse Particles 1: 101-114.

Alberti, G. 2000. Lifelong discourse representation structures. Gothenburg Papers in Computational Linguistics 005: $13-20$.

Alberti, G. 2011. ReALIS. Interpretálók a világban, világok az interpretálóban [Interpreters in the World, Worlds in the Interpreter]. Budapest, Hungary: Akadémiai Kiadó.

Alberti, G., M. Dóla, E. Kárpáti, J. Kleiber, A. Szeteli, and A. Viszket. 2019a. Towards a cognitively viable linguistic representation. Argumentum 15: 62-80.

Alberti, G., M. Dóla, E. Kárpáti, J. Kleiber, A. Szeteli, and A. Viszket. 2019b. Kérdéses világaink [Our Worlds in Question(s)]. Jelentés és Nyelvhasználat [Meaning and Language Use] 6: 11-35.

Alberti, G., and J. Farkas. 2018. A syntactic solution to the inverse-scope puzzle and the contrastive VP-focus construction in Hungarian based on extraction. In A. Bloch-Rozmej and A. Bondaruk (eds.), Studies in Formal Linguistics, 35-54. Berlin, Germany: Peter Lang.

Alberti, G., and J. Kleiber. 2015. ReALIS: Discourse representation with a radically new ontology. In L. Veselovská and M. Janebová (eds.), Complex visibles out there: Olomouc modern language series 4, 513-528. Olomouc, Czech Republic: Palacký University.

Alberti, G., J. Kleiber, Zs. Schnell, and V. Szabó. 2016. Intensional profiles and different kinds of human minds: "Case studies" about Hungarian imperative-like sentence types. Linguistics Beyond And Within 2: 6-26.

Andor, J. 2011. Reflections on Speech Act Theory: An interview with John R. Searle. International Review of Pragmatics 3: 1-12.

Bánréti, Z. 1992. A mellérendelés [Coordination]. In F. Kiefer (ed.), Strukturális magyar nyelvtan 1 [A Structural Grammar of Hungarian 1], 715-796. Budapest, Hungary: Akadémiai Kiadó.

Brody, M. 1990. Remarks on the order of elements on the Hungarian Focus Field. In I. Kenesei (ed.), Approaches to Hungarian 3, 95-121. Szeged, Hungary: JATE.

É. Kiss, K. 1992. Az egyszerü mondat szerkezete [The structure of the simple clause]. In F. Kiefer (ed.), Strukturális magyar nyelvtan 1 [A Structural Grammar of Hungarian 1], 79-177. Budapest, Hungary: Akadémiai Kiadó.

É. Kiss, K. 2002. The syntax of Hungarian. Cambridge, UK: Cambridge University Press.

É. Kiss, K. 2009. Is free postverbal order in Hungarian a syntactic or a PF phenomenon? In N. Erteschik-Shir and L. Rochman (eds.), The sound pattern of syntax, 53-71. Oxford, UK and New York, USA: Oxford University Press.

Farkas, D. and F. Roelofsen. 2017. Division of Labor in the Interpretation of Declaratives and Interrogatives. Journal of Semantics 34: 237-289.

Farkas, J. and G. Alberti. 2017. The Hungarian HATNÉK-noun expression: A hybrid construction. In A. BlochRozmej and A. Bondaruk (eds.), Constraints on structure and derivation in syntax, phonology and morphology, 71-100. Frankfurt am Main, Germany: Peter Lang.

Fischer, K. 2006. Towards an understanding of the spectrum of approaches to discourse particles: Introduction to the volume. In K. Fisher (ed.), Approaches to discourse particles, 1-20. Amsterdam, The Netherlands: Elsevier.

Futó, B. 2020. A logikai is-től a pragmatikai is-en át a metakognitív is-ig [From the logical is through the pragmatic is to the metacognitive is]. In G. Böhm, D. Czeferner, and T. Fedeles (eds.), Specimina Operum Iuvenum 6, 13-49. Pécs, Hungary: PTE BTK Scientific Students Circle.

Grohmann, K. K. 2003. Prolific domains: On the anti-locality of movement dependencies. Linguistik Aktuell 66. Amsterdam, The Netherlands: John Benjamins.

Huszics, A. 2020. Szintén [Also]. In G. Böhm, D. Czeferner, and T. Fedeles (eds.), Specimina Operum Iuvenum 6, 50-84. Pécs, Hungary: PTE BTK Scientific Students Circle.

Kamp, H., J. van Genabith, and U. Reyle. 2011. Discourse representation theory. In D. Gabbay and F. Guenthner (eds.), Handbook of philosophical logic 15, 125-394. Berlin: Springer.

Kleiber, J. and G. Alberti. 2017. Compositional analysis of interrogative imperatives in Hungarian. Linguistics Beyond And Within 3: 117-135.

Lauer, S. 2013. Towards a dynamic pragmatics. Ph.D. diss. Stanford University. 
Leiss, E. 2014. Modes of modality in an Un-Cartesian framework. In S. Cantarini, W. Abraham, and E. Leiss (eds.) Certainty-uncertainty - and the attitudinal space in between. Studies in language companion series 165, 4762. Amsterdam, The Netherlands: Benjamins.

Surányi, B. 2008. Határozóosztályok és mondattartományok [Adverbial classes and sentence domains]. Nyelvtudományi Közlemények [Issues in linguistics] 105: 163-192.

Surányi, B. 2009. “Incorporated” locative adverbials in Hungarian. In K. É. Kiss (ed.), Adverbs and adverbial adjuncts at the interfaces, 39-74. Berlin, Germany: Mouton de Gruyter.

Szeteli, A. and Alberti, G. 2018. The interaction between relevant-set based operators and a topic-predicate dimension. Linguistics Beyond And Within 4: 161-172.

Szeteli, A., M. Dóla, and G. Alberti. 2019. Pragmasemantic analysis of the Hungarian inferential-evidential expression 'szerint'. Studies in Polish Linguistics 14: 207-225.

Viszket, A., A.Hoss, E. Kárpáti, and G. Alberti. 2019. Recalculating: The atlas of pragmatic parameters of developmental disorders. Linguistics Beyond And Within 5, 148-160. 